\title{
ZIELEŃ O SPECJALNYM PRZEZNACZENIU NA PRZYKŁADZIE KONCEPCJI ZAGOSPODAROWANIA OGRODU PRZY WOJEWÓDZKIM SZPITALU ZESPOLONYM W TORUNIU
}

\author{
SPECIAL PURPOSE VEGETATION ON THE EXAMPLE OF A GARDEN \\ DEVELOPMENT CONCEPT AT THE PROVINCIAL POLYCLINIC HOSPITAL \\ IN TORUŃ
}

\author{
Mitosz Walerzak, Anna Walerzak
}

\begin{abstract}
M. Walerzak, Katedra Terenów Zieleni i Architektury Krajobrazu, Uniwersytet Przyrodniczy w Poznaniu, ul. Dąbrowskiego 159, 60-594 Poznań, Poland, e-mail: milosz.walerzak@up.poznan.pl

A. Walerzak, e-mail: anna.walerzak@wp.pl
\end{abstract}

\begin{abstract}
AвSTRACT. Every garden is therapeutic in a way. When we are surrounded by plants, we often do not realise the fact that all our senses perceive the space, composition and its elements. Plants can be used for relaxation, recreation, rehabilitation, therapy, education and sports. Therapeutic gardens stimulate all the five senses, i.e. the sight, hearing, taste, smell and touch. When creating a therapeutic garden, one of the main rules is to design the whole composition, select the programme and its elements so as to minimise the intensity of visual stimuli. All the other senses should play the main role. Horticultural therapy requires the application of appropriate architectural and landscaping rules and solutions, such as a specialised adjusted garden programme, spatial composition, appropriate surface and equipment for disabled people, elevated flowerbeds and adequate selection of plants. Vegetation plays an important role in therapeutic gardens, especially in those providing horticultural therapy. Plants should not be treated exclusively as aesthetic (visual) material, but also as elements, components and materials which are widely used in therapies. Therefore, the primary role of vegetation in these gardens is to offer therapeutic properties, which affect the sanitary conditions in a particular environment.
\end{abstract}

KEY WORDS: horticultural therapy, special garden, garden therapy, hospital garden

\section{WSTĘP}

Ogrody w ogólnym ujęciu - to tereny o ogromnych wartościach terapeutycznych. Przebywając w nich, odbieramy ich przestrzeń, kompozycję i poszczególne elementy wszystkimi zmysłami. Jednak postrzeganie otoczenia za pomocą zmysłu wzroku jest tak intensywne, że całą uwagę skupiamy głównie na tej formie odbierania bodźców zewnętrznych. Pozostałe cztery zmysły (słuch, smak, węch i dotyk) schodzą na dalszy plan, towarzysząc przekazowi wzrokowemu lub uzupełniając go, wzbogacając lub czasem wręcz przeciwnie - zakłócając.

Układy zieleni komponowanej, takie jak ogrody i parki, oddziałują na ludzi, a szczególnie na dzieci.
Te młodsze i najmłodsze grupy użytkowników bardzo intensywnie chłoną otwartą przestrzeń ogrodową wszystkimi zmysłami. Nie potrzebują szczególnie wymyślnych elementów towarzyszących i uatrakcyjniających im spędzanie tam czasu. „Pod wpływem przyrody dziecko staje się silniejsze i odporniejsze na wiele chorób. Przyroda wzmaga apetyt, przywraca sen, wzmacnia system nerwowy, pobudza aktywność całego organizmu. Rozwija poczucie piękna i wrażliwość, dostarcza wielu radosnych, a zarazem subtelnych przeżyć. Jest też nieocenionym wychowawcą i nauczycielem. Różne zjawiska przyrodnicze wywołują u dziecka pasję poznawczą, ćwiczą spostrzegawczość, uwagę, wyrabiają zmysł obserwacyjny i instynkty opiekuńcze" (PALej 1991). 
Jedną z głównych zasad tworzenia ogrodu o specjalnym przeznaczeniu (np. przyszpitalnego) jest projektowanie całego układu kompozycji oraz dobór programu i poszczególnych elementów tak, aby natężenie bodźców wzrokowych było jak najmniejsze.

Ogród może wpływać na zmysł:

- słuchu - poprzez odgłosy szelestu liści roślin, śpiew ptaków w koronach drzew, szum wody, owady,

- węchu - poprzez zapachy: roślin (kwiatów i liści), wody, ale również skoszonej trawy, mokrych liści,

- smaku - poprzez jadalne zioła, owoce i warzywa.

- dotyku - poprzez różnorodność kształtów, struktur i form roślin oraz elementów wyposażenia,

- wzroku - poprzez wielobarwne układy roślin, a także grę światła i cienia, barwy kwiatów, liści i pędów oraz promienie słońca przeświecające przez listowie.

Równie ważne wydają się odczuwalne zmysłami aspekty dotyczące:

- zmienności w czasie (inny wygląd i nastrój w zależności od pory roku, miesiąca, dnia, oświetlenia, zachmurzenia, zastosowanych roślin i materiałów),

- możliwości obserwacji współistnienia różnorodnych organizmów,

- tworzenia wnętrz - mniejszych lub większych (sterowanie liczbą użytkowników i przeznaczeniem),

- możliwości spędzania czasu na świeżym powietrzu (wypoczynek na lawce, spacer, uprawianie sportów).

Ogród sensualny, który jest odbierany za pomocą wszystkich zmysłów, lub hortiterapeutyczny, czyli wykorzystujący terapię ogrodniczą (terapię „ogrodem"), w doskonały sposób wspomaga metody konwencjonalne.

Hortiteriapia polega na interdyscyplinarnym działaniu medycyny, ogrodnictwa i zasad terapii w celu poprawy stanu zdrowia ludzi. Terapia w ogrodzie wiąże się z zastosowaniem odpowiednich zasad i rozwiązań architektoniczno-krajobrazowych. W ogrodach hortiterapeutycznych ważne jest uwzględnienie kilku istotnych elementów przestrzennych i zasad, takich jak:

- uniesione rabaty - czyli grządki, kwietniki, murki oporowe, które dzięki odpowiedniej wysokości obsadzeń roślinnych umożliwiają bezpośredni kontakt wzrokowy i dotykowy z pozycji siedzącej i stojącej. Podniesienie ich na wysokość $50-90 \mathrm{~cm}$ ułatwi ich pielęgnację i użytkowanie przez osoby starsze i na wózkach inwalidzkich, umożliwi także dzieciom doskonały dostęp do roślin;

- elementy wodne stymulujące zmysł słuchu i dotyku - szczególnie cenione są urządzenia $z$ wodą w ruchu, czyli: nieduże fontanny, kaskady, sztuczne strumyki;

- pionowe ogrody - dzięki zastosowaniu odpowiedniej konstrukcji drewnianej lub metalowej na pionowych ścianach umieszcza się rośliny, które oprócz walorów estetycznych i wizualnych zapewniają dostęp zarówno z pozycji siedzącej, jak i stojącej. Wertykalne ogrody są szczególnie pożądane $\mathrm{w}$ małych ogrodach terapeutycznych, minimalizując powierzchnię niezbędną dla wprowadzenia roślin;

- wiszące donice $z$ roślinami - rośliny sadzi się $\mathrm{w}$ podwieszanych donicach, których wysokość może być zmieniana $\mathrm{w}$ zależności od potrzeb osób pielęgnujących czy obserwujących. W niedużych ogrodach rośliny w wiszących pojemnikach zwiększają liczbę elementów roślinnych i wzbogacają program terapii. Podwieszone pojemniki nie zajmują nawierzchni znajdującej się pod nimi, dzięki czemu można ją wykorzystać do innych zajęć terapeutycznych;

- elementy poziome związane $z$ nawierzchnią - to ścieżki rehabilitacyjne pokryte materiałami o zróżnicowanej fakturze, kolorze czy właściwościach akustycznych. Ścieżki te powinny być wzbogacone o dodatkowe elementy, takie jak: poręcze, spoczniki, nieduże siedziska oraz elementy urozmaicające i zachęcające do przebycia drogi, tj. rzeźby kamienne, rzeźby foniczne, karmniki, elementy drewniane czy związane z przepływem wody;

- zastosowanie kompozycji roślinnych cechujących się: bogatą różnorodnością kształtów i tekstur liści, owoców, kwiatów, łodyg, które umożliwi kształtowanie i rozwój zmysłu dotyku;

- zastosowanie roślin o silnych i zróżnicowanych zapachach kwiatów, liści i pędów wpłynie na sensory węchu, na przykład ziół, przy czym należy unikać tych roślin, które mają właściwości trujące, parzące, alergizujące, silnie ciernistych i o twardych igłach (DĄBSKK \& DudKIEwICZ 2010).

Analiza poszczególnych czynników, takich jak natężenie hałasu (ryc. 1), wielkość i kształt dział$\mathrm{ki}$, klimat, ukształtowanie terenu, szata roślinna, wilgotność powietrza, wiatr, temperatura oraz promieniowanie słoneczne, ma zasadniczy wpływ na powstanie projektu ogrodu terapeutycznego. Przeanalizowanie tych aspektów prowadzi do ustalenia zasad projektowych, którymi należy się kierować,

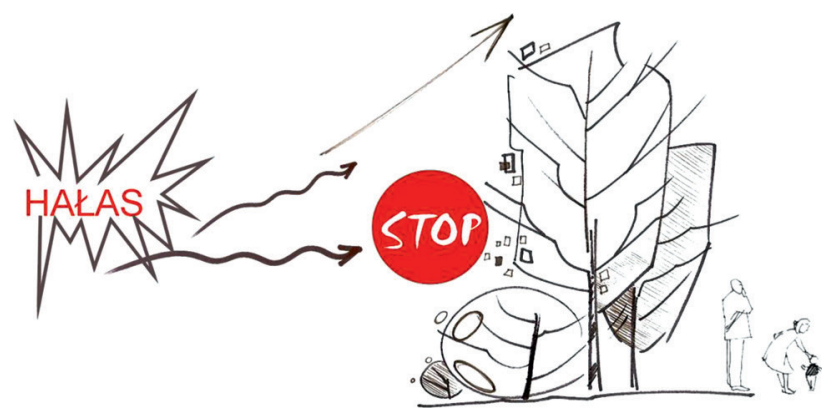

Ryc. 1. Wpływ ekranizacji roślinnej na klimat akustyczny miejsca

Źródło: opracowanie A. Walerzak.

Fig. 1. Vegetation as a natural noise barier

Source: developer by A. Walerzak. 
chcąc stworzyć obiekt spełniający warunki dogodne dla przyszłych użytkowników.

Zasadniczą rolę w kształtowaniu ogrodów o specjalnym przeznaczeniu, np. terapeutycznych, pełni odpowiednio dobrana i zakomponowana roślinność. Dlatego nie należy traktować roślinności wyłącznie jako tworzywa o walorach estetycznych (wizualnych). Oddziałuje ona również na układ klimatyczno-zdrowotny na danym terenie, a swoim szerokim zasięgiem wpływa na ukształtowanie warunków klimatycznych reszty miasta.

W przypadku najmłodszych użytkowników odpowiedni dobór roślin zastosowanych w ogrodzie terapeutycznym może stymulować oraz inspirować do różnorodnych działań, zajęć i terapii. Całe rośliny (drzewa, krzewy) lub ich fragmenty (liście, owoce, kwiaty, pędy, kawałki kory) są wykorzystywane przez dzieci do wielu przemyślanych lub całkiem spontanicznych zabaw (ZALEWSKA \& WALTER 2011).

W niedużych obiektach (ogrodach) obsadzenia powinny mieć formy regularne, zgeometryzowane, natomiast na terenach o większej powierzchni istnieje możliwość pełnego rozwinięcia kompozycji roślinnej, z wykorzystaniem układów wielownętrzowych i naturalistycznych.

Celem pracy było stworzenie koncepcji ogrodu o specjalnym przeznaczeniu przy Wojewódzkim Szpitalu Zespolonym w Toruniu.

\section{MATERIAŁ I METODY}

\section{ZAŁOŻENIA KOMPOZYCYJNE OGRODU}

Przykładem zieleni o specjalnym przeznaczeniu może być koncepcja zagospodarowania ogrodu przy Wojewódzkim Szpitalu Zespolonym im. Ludwika Rydygiera w Toruniu, wykonana na podstawie wniosków sformułowanych między innymi na podstawie analiz terenu opracowania oraz badań społecznych przeprowadzonych wśród personelu i pacjentów szpitala (ryc. 2).

Zasadniczą rolą stworzenia koncepcji zagospodarowania ogrodu stało się nadanie mu fundamentalnych funkcji jako przestrzeni pomocnej chorym $\mathrm{w}$ rekonwalescencji.

Analizując stan ogrodu oraz jego obecny układ funkcjonalno-przestrzenny (ryc. 3), określono główne mankamenty tego terenu.

Do najważniejszych mankamentów można zaliczyć:

- brak ogrodzenia,

- brak dobrze rozwiniętego układu komunikacji,

- niespełnianie funkcji leczniczo-rekreacyjnych,

- niezapewnianie spokoju i bezpieczeństwa podczas rekonwalescencji,

- brak dostępu do istniejących zbiorników wodnych oraz ich zły stan biologiczny,
- brak kompozycji przestrzeni dla korzystających $z$ ogrodu,

- przewaga strefy niewykorzystanej funkcjonalnie. Główne założenia projektowe przyjętej koncepcji ogrodu terapeutycznego to:

- powiększenie powierzchni użytkowej terenu ogrodu oraz nadanie jej funkcji zdrowotnych,

- stworzenie układu stref funkcjonalnych służących poprawie zdrowia i jakości życia pacjentów,

- nadanie ogrodowi statusu obiektu zamkniętegoprzez zaprojektowanie i uzupełnienie ogrodzenia, co poprawi komfort psychiczny pacjentów, zapobiegając swobodnemu przepływowi osób spoza terenu szpitala,

- likwidacja barier dla ludzi niepełnosprawnych i dbałość o pełną integrację wszystkich użytkowników, bez względu na stan zdrowotny,

- zapewnienie użytkownikom pełnej rekreacji ruchowej oraz wielu możliwości odbioru ogrodu dzięki bezkolizyjnemu układowi komunikacji pieszej oraz swobodzie w sposobie jego przemierzania,

- oddziaływanie ogrodu na zmysły: wzroku, węchu, słuchu i dotyku - dzięki zróżnicowanej funkcjonalności i zastosowanemu programowi,

- likwidacja niepokojących ostrych kształtów, ciasnych wnętrz, nagromadzenia elementów przestrzennych na korzyść form zaokrąglonych, dobrze oświetlonych wnętrz (szczególnie w porze

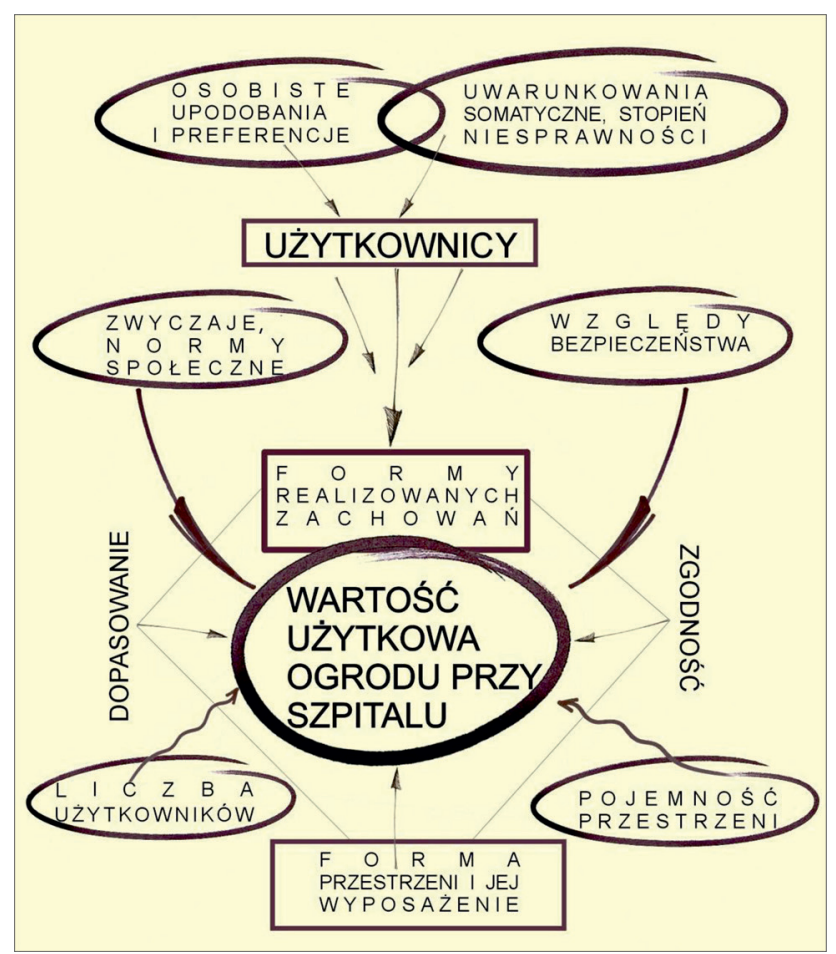

Ryc. 2. Wpływ ukształtowania form przestrzennych środowiska na jego wartość użytkową Źródło: opracowanie A. Walerzak.

Fig. 2. Impact of terrain on its use value Source: developer by A. Walerzak. 


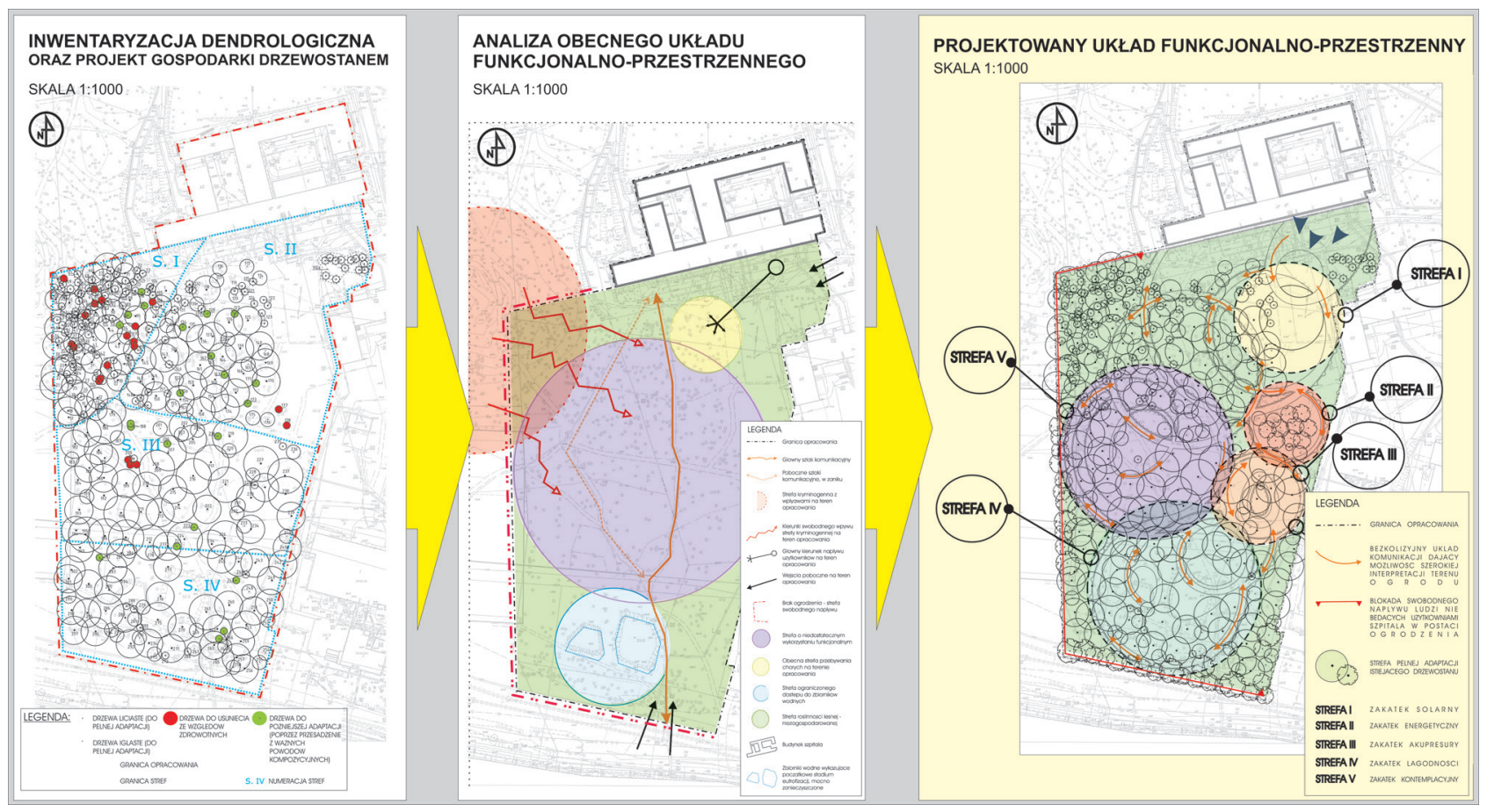

Ryc. 3. Stan istniejący obiektu - inwentaryzacja i analiza obecnego funkcjonowania oraz wynikający z tego proponowany schemat funkcjonalno-przestrzenny

Źródło: opracowanie A. Walerzak.

Fig. 3. Existing state of the object - greenery inventory, functional analysis and proposed functional scheme Source: developer by A. Walerzak.

Tabela 1. Szczegółowy program koncepcji zagospodarowania terenu ogrodu Table 1. Detailed program of a concept of the garden area

\begin{tabular}{|c|c|c|c|c|}
\hline $\begin{array}{l}\text { Lp. } \\
\text { No. }\end{array}$ & $\begin{array}{l}\text { Nazwa } \\
\text { Name }\end{array}$ & $\begin{array}{l}\text { Części składowe } \\
\text { Components }\end{array}$ & $\begin{array}{l}\text { Program } \\
\text { Program }\end{array}$ & $\begin{array}{l}\text { Wyposażenie } \\
\text { Equipment }\end{array}$ \\
\hline Strefa I & Zakątek solarny & - podest do kąpieli słonecznych & $\begin{array}{l}\text { - strefa udostępniona pod kąpiele } \\
\text { słoneczne, realizacja fotote- } \\
\text { rapii, } \\
\text { - pełna dostępność dla osób } \\
\text { niepełnosprawnych }\end{array}$ & $\begin{array}{l}\text { - drewniany podest, } \\
\text { - drewniane leżaki }\end{array}$ \\
\hline Strefa II & Zakątek energetyczny & - zagajnik brzozy brodawkowatej & $\begin{array}{l}\text { - medytacja oraz czerpanie pozy- } \\
\text { tywnej energii z drzew, } \\
\text { - pełna dostępność dla osób } \\
\text { niepełnosprawnych }\end{array}$ & - \\
\hline Strefa III & Zakątek akupresury & $\begin{array}{l}\text { - układ ruchomych siedzisk } \\
\text { z możliwością dogodnej inter- } \\
\text { pretacji aranżowania przestrzeni, } \\
\text { - pasmo otoczaków usypanych } \\
\text { wokół drewnianego podestu, } \\
\text { - drewniany podest do wypoczyn- } \\
\text { ku między masażami }\end{array}$ & $\begin{array}{l}\text { - strefa przeznaczona do akupre- } \\
\text { sury stóp, } \\
\text { - możliwość swobodnego aranżo- } \\
\text { wania przestrzeni przez układ } \\
\text { mobilnych siedzisk, } \\
\text { - pełna dostępność dla osób } \\
\text { niepełnosprawnych }\end{array}$ & $\begin{array}{l}\text { - ruchome siedziska po- } \\
\text { ruszające się wzdłuż } \\
\text { półkolistej szyny, } \\
\text { - drewniany podest }\end{array}$ \\
\hline Strefa IV & Zakątek łagodności & $\begin{array}{l}\text { - zbiorniki wodne, } \\
\text { - drewniany podest } z \text { wkompono- } \\
\text { wanym pomostem }\end{array}$ & $\begin{array}{l}\text { - strefa kojąca zmysł słuchu } \\
\text { dzięki dostępowi do wody, } \\
\text { - pełna dostępność dla osób } \\
\text { niepełnosprawnych }\end{array}$ & $\begin{array}{l}\text { - podest drewniany } \\
\text { z pomostem }\end{array}$ \\
\hline Strefa V & Zakątek kontemplacyjny & $\begin{array}{l}\text { - zaaranżowane pole lawendowe } \\
\text { w układzie wyższych krzewów }\end{array}$ & $\begin{array}{l}\text { - strefa intymnej izolacji uzyska- } \\
\text { na dzięki posadzeniu wyższych } \\
\text { krzewów, } \\
\text { - realizacja aromaterapii, } \\
\text { - pełna dostępność dla osób nie- } \\
\text { pełnosprawnych }\end{array}$ & - \\
\hline
\end{tabular}

Źródło: opracowali A. Walerzak, M. Walerzak.

Source: developer by A. Walerzak, M. Walerzak. 
wieczornej) oraz wyważonych kompozycyjnie i ilościowo detali wyposażenia,

- pełna adaptacja istniejącej roślinności drzewiastej, uzupełnienie kompozycji zróżnicowaną roślinnością o funkcjach fitoterapeutycznychoraz wprowadzenie układów roślinnych w niższych partiach, pod koronami drzew,

- poprawienie jakości odbioru wizualno-estetycznego ogrodu poprzez zaproponowaną kompozycję przestrzenną elementów składowych: roślinności, zbiorników wodnych, układu komunikacji, elementów wyposażenia.

\section{WYNIKI \\ KONCEPCJA I ELEMENTY \\ ZAGOSPODAROWANIA OGRODU PRZYSZPITALNEGO}

Ogród może stać się miejscem, w którym organizm wycisza się, uspokaja, nabiera energii, odnajduje radość. Wszystkie te właściwości można wzmocnić przez zastosowanie odpowiedniego rodzaju terapii.
Struktura programowo-przestrzenna opiera się na podziale ogrodu na pięć stref funkcjonalnych, z uwzględnieniem pełnej adaptacji istniejącego drzewostanu. Uzupełniono zdewastowane ogrodzenie, przywracając obiektowi status ogrodu przyszpitalnego. Rozwinięto bezkolizyjny układ komunikacji dający wiele możliwości przemierzania ogrodu w sposób dogodny dla poszczególnych użytkowników, a także organizowania różnych terapii. Funkcjonalność stref spowodowała, iż w proponowanej koncepcji ogród zyskał funkcję leczniczo-rekreacyjną. Dzięki zaprojektowaniu zróżnicowanych wnętrz zapewniono pacjentom spokój i bezpieczeństwo podczas rekonwalescencji. Udostępniono również strefę nadwodną.

Obszar ogrodu zaaranżowano w układzie pięciu głównych stref funkcjonalnych (ryc. 4, 5, 6, tab. 1):

- strefa I - zwana dalej zakątkiem solarnym, pow. ok. 0,39 ha

- strefa II - zwana dalej zakątkiem energetycznym, pow. ok. 0,14 ha

- strefa III - zwana dalej zakątkiem akupresury, pow. ok. 0,19 ha

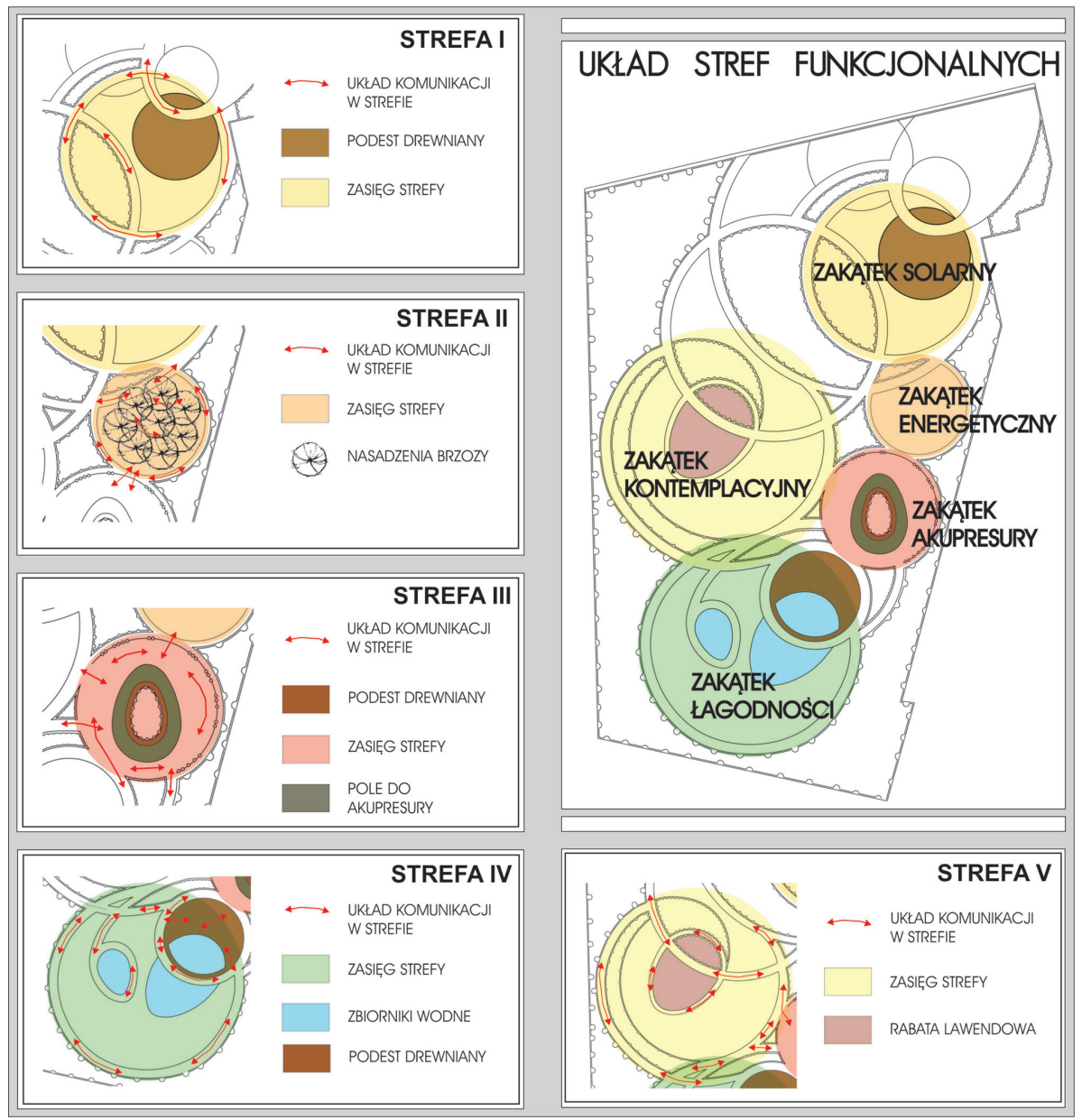

Ryc. 4. Ogólny układ i szczegółowy schemat poszczególnych stref funkcjonalnych Źródło: opracowanie A. Walerzak.

Fig. 4. General layout and detailed zones diagram

Source: developer by A. Walerzak. 


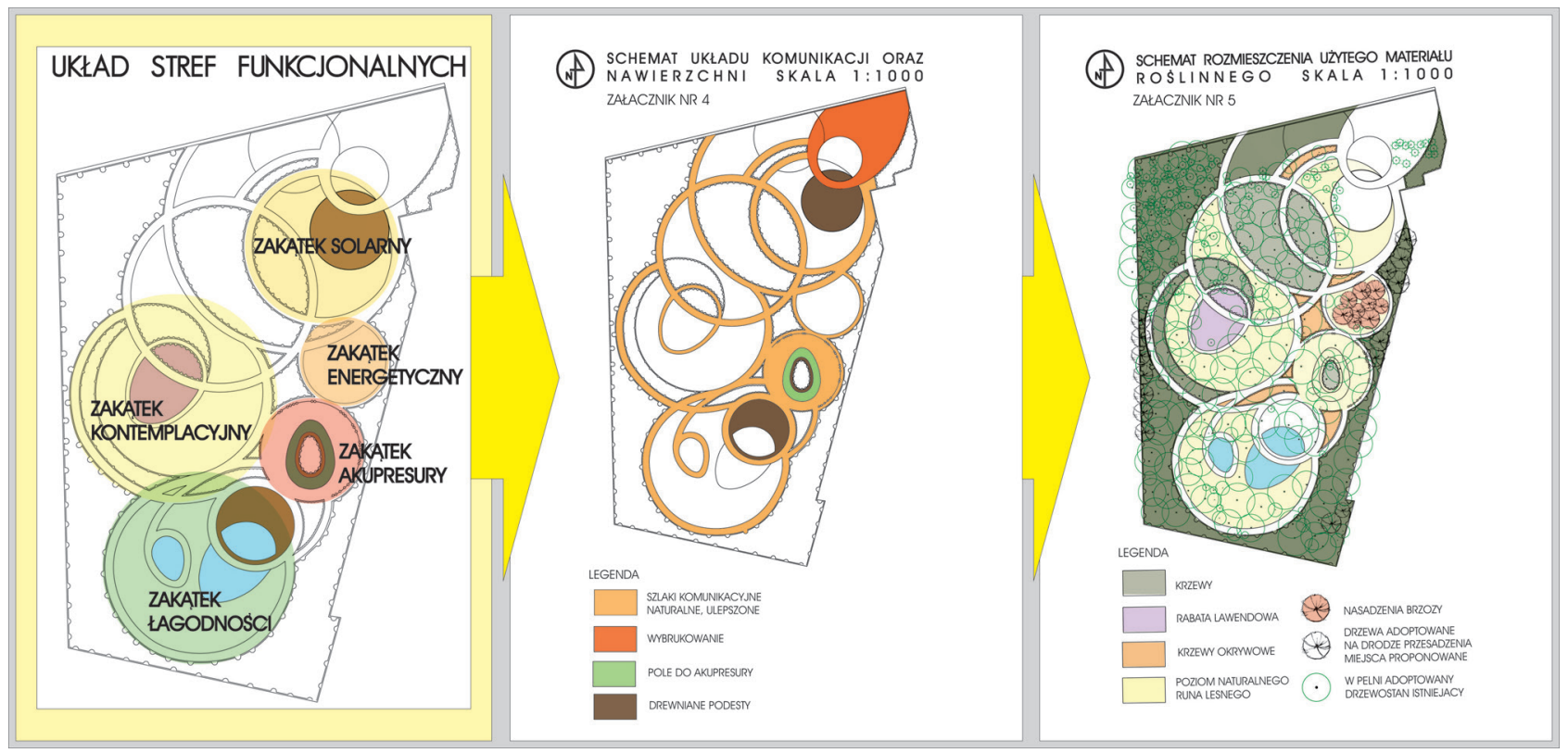

Ryc. 5. Układ proponowanych stref funkcjonalnych oraz schematy projektowanej komunikacji i głównych układów roślinnych

Źródło: opracowanie A. Walerzak.

Fig. 5. The arrangement of the proposed functional zones, communication system diagram and a diagram of a main plant systems

Source: developer by A. Walerzak.

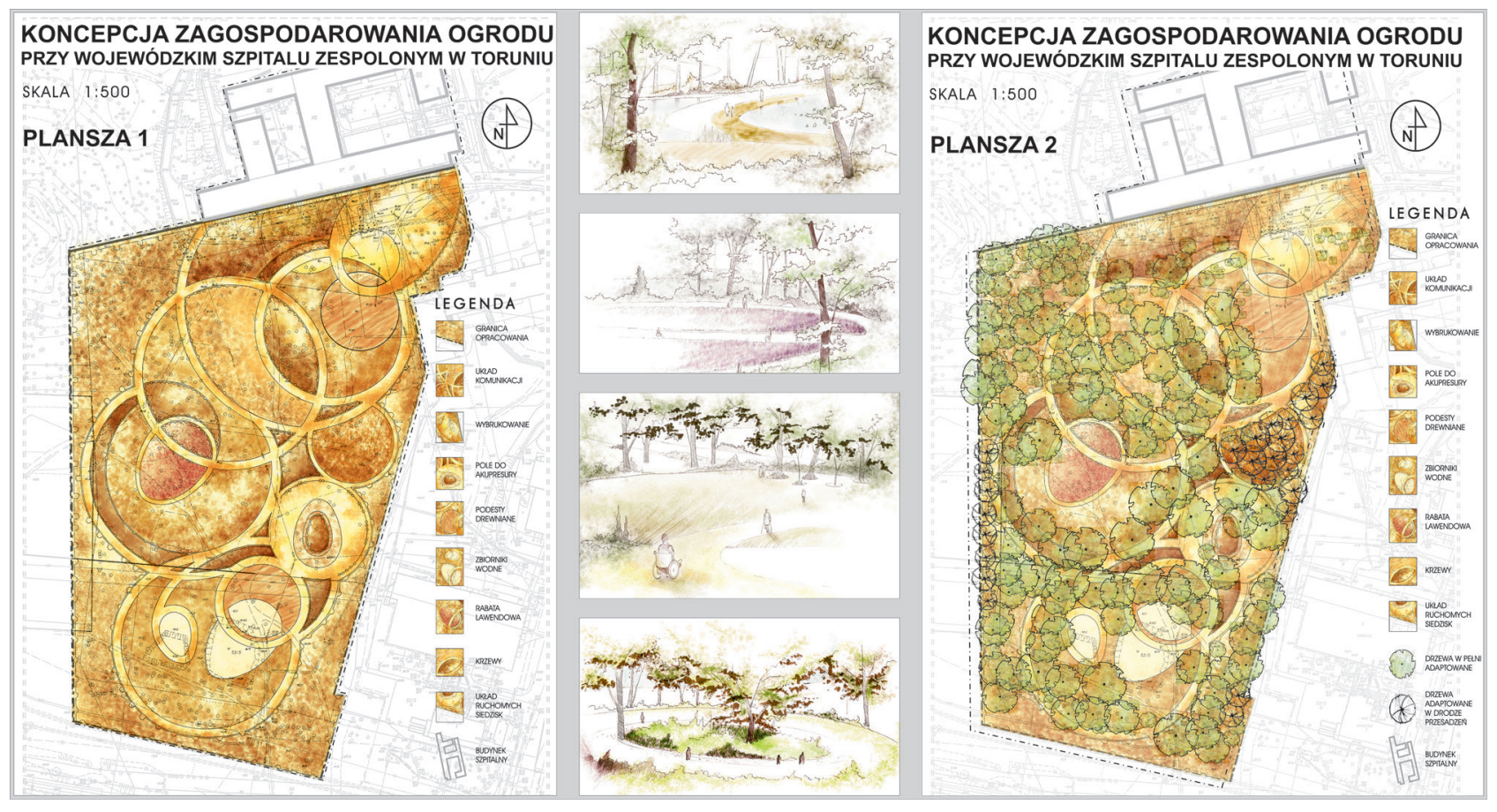

Ryc. 6. Koncepcja zagospodarowania ogrodu terapeutycznego: plansza 1 - ogólna koncepcja układu drogowego, placów, elementów przestrzennych oraz układów i kompozycji roślinności średniej i niskiej, wybrane wizualizacje obiektu, plansza 2 - ogólna koncepcja wraz z naniesionym układem adaptowanych drzew istniejących oraz drzew projektowanych

Źródło: opracowanie A. Walerzak.

Fig. 6. Development concept of a therapeutic garden: board 1 - general concept; board 2 - general concept along with adapted and designed trees

Source: developer by A. Walerzak. 
- strefa IV - zwana dalej zakątkiem łagodności, pow. ok. 0,56 ha

- strefa V - zwana dalej zakątkiem kontemplacyjnym, pow. ok. 0,75 ha.

Charakterystykę poszczególnych stref przedstawiono w tabeli 1.

\section{STREFA I}

Zakątek solarny ma ułatwić użytkownikom bezpieczne kąpiele słoneczne w bezchmurne dni. Na drewnianym podeście, $\mathrm{w}$ jego centralnym punkcie, mogą przebywać osoby chcące czerpać siłę i dobre samopoczucie $z$ energii słonecznej. Strefa została zlokalizowana $\mathrm{w}$ północno-wschodnim narożniku prezentowanego terenu ze względu na niewielki stopień zadrzewienia w stosunku do reszty ogrodu, dzięki czemu promieniowanie słoneczne dociera do ziemi bez zakłóceń i nie jest konieczne ciągłe „podążanie” za wędrującym w ciągu dnia słońcem. Bliskość zakątka solarnego od wejścia do budynku szpitalnego ułatwia korzystanie $z$ kąpieli słonecznych osobom, które nie są $\mathrm{W}$ stanie lub nie powinny oddalać się od szpitala zbyt daleko. Jednocześnie okalający strefę układ szerokich ścieżek umożliwia niedalekie spacery w pełnej ekspozycji słonecznej. Szerokość ścieżek pozwala na swobodne mijanie się osób poruszających się o kulach czy też na wózku inwalidzkim. Podest do kapieli słonecznych i odpoczynku został zaprojektowany na poziomie gruntu, dlatego strefa I jest pozbawiona jakichkolwiek barier architektonicznych dla osób niepełnosprawnych, zwłaszcza poruszających się na wózkach inwalidzkich.

\section{STREFA II}

Zakątek energetyczny powstał z myślą o wykorzystaniu rezonansu energetycznego między człowiekiem a roślinami, zwłaszcza drzewami. Wiedzieli o tym starożytni, dlatego otaczali niektóre drzewa wielkim szacunkiem, a nawet kultem. Na przykład druidyzm, religia Celtów, opierał się właśnie na kulcie drzew, w myśl którego życie drzewa było niekiedy ważniejsze niż życie człowieka. Nasi przodkowie nie mieli przytępionych techniką zmysłów i wyczuwali płynące od drzew dobroczynne energie. Nie powinniśmy odrzucać ich mądrości. Jeśli zwrócimy baczną uwagę na to, jak się zachowujemy i jak się czujemy wśród drzew, zauważymy ich dobroczynny wpływ na nasze samopoczucie. Drzewa oddziałują na człowieka, porządkując jego wewnętrzną energię, ponieważ wytwarzają jonizację ujemną, tak bardzo człowiekowi potrzebną. Szczególnie dobre oddziaływanie mają brzozy brodawkowate (Betula pendula Roth).

Te właściwości „drzewoterapii” stały się kanwą do powstania koncepcji zakątka energetycznego. Jednolita zwarta grupa brzozy brodawkowatej w centralnej części strefy II ułatwi użytkownikom skoncentrowanie się na czerpaniu z tego przyjaznego drzewa zbawiennej dla człowieka energii i zaoszczędzi czasu na szukanie brzóz w innych częściach ośrodka.

\section{STREFA III}

Zakątek akupresury - dzięki zastosowaniu szerokiego pasa wysypanego niewielkimi, bezpiecznymi otoczakami (kamienie o okrągłych, gładkich kształtach) - ma za zadanie zbliżyć człowieka do tej niekonwencjonalnej metody leczenia wspomagającej medycynę konwencjonalną. Akupresura wywodzi się z medycyny chińskiej. Jest naturalną metodą leczniczą starszą od akupunktury. Lekarze medycyny konwencjonalnej podchodzą do niej z dużą ostrożnością, ale wielu ją popiera jako sposób samopomocy. W rękach profesjonalisty akupresura i masaż chiński mogą stanowić pełnowartościowe narzędzia lecznicze, $\mathrm{w}$ innych przypadkach akupresura może być stosowana tylko objawowo. Dlatego w razie wystąpienia dolegliwości nigdy nie powinno się rezygnować $\mathrm{z}$ porady lekarskiej ani ignorować zaleceń lekarza.

Podstawą do powstania koncepcji zakątka akupresury stała się konkretna gałąź akupresury - akupresura stóp. Temu celowi służy szerokie pasmo otoczaków w centralnej części strefy III. Uzytkownicy ogrodu mogą bosymi stopami przemierzać określone odcinki kamiennej ścieżki, w razie potrzeby odpoczywając na biegnacym równolegle drewnianym podeście, który dzięki materiałowi, z jakiego jest zbudowany, sprawia, że nie odczuwa się dyskomfortu związanego $z$ chodzeniem na bosaka po zimnym podłożu. W tej strefie znajdują się także mobilne siedziska, które poruszają się po półkolistej szynie, umożliwiając swobodne kreowanie przestrzeni przez użytkowników. Dzięki możliwości przesuwania siedzisk dowolna liczba osób może się swobodnie skupiać we własnym sąsiedztwie. Z kolei inni użytkownicy mogą się od nich odłączyć. Zapewnia to poczucie intymności, swobody i niezależności. Opisywana przestrzeń może być dowolnie aranżowana i wykorzystywana do prowadzenia wybranych grupowych zajęć terapeutycznych. Siedziska najlepiej zaprojektować w zróżnicowanych kolorach, co poszerzy strefę III o funkcję koloroterapii.

\section{STREFA IV}

Zakątek łagodności spełnia założenia projektowe dzięki oczyszczeniu i pozostawieniu $\mathrm{w}$ nim istniejących zbiorników wodnych. Obecność wody to ważny element składowy w kształtowaniu krajobrazu. Strefa IV staje się czynnikiem pobudzającym zmysł wzro$\mathrm{ku}$ (fascynująco i niezwykle wygląda lustrzane odbicie otaczających wodę roślin, zwłaszcza w pogodny dzień, gdy niebo jest błękitne), ale przede wszystkim zmysł słuchu człowieka. Paradoksalnie w ogrodzie możemy odnaleźć absolutny spokój, ale nigdy nie odnajdziemy absolutnej ciszy (TACZANOwsKa 2005), 
choćby dzięki odgłosom wody czy ptaków gnieżdżących się w koronach drzew. Woda wykorzystana w opisywanym założeniu projektowym działa na człowieka uspokajająco, sprzyjając rekonwalescencji.

Kształt zbiorników nawiązuje do ogólnej koncepcji zagospodarowania. Na jednym ze zbiorników umieszczono pomost, wkomponowany $\mathrm{w}$ drewniany podest graniczący ze zbiornikiem, dzięki czemu kontakt użytkownika ogrodu z wodą staje się jeszcze silniejszy.

W tej części ogrodu chorzy z łatwością mogą znaleźć spokój i być może choć na chwilę zapomnieć o swoich niedomaganiach. Strefa jest całkowicie dostosowana do potrzeb osób niepełnosprawnych, poruszających się o kulach, czy też na wózku inwalidzkim.

\section{STREFA V}

Zakątek kontemplacyjny powstał z myślą o kojeniu stanów nerwowych przez aromaterapię. W jego centralnej części zlokalizowano pole lawendy (Lavandula angustifolia), które dzięki swoim właściwościom aromaterapeutycznym wspomaga kontemplację użytkowników na świeżym powietrzu.

Aromaterapia to forma leczenia $z$ użyciem zapachów i lotnych substancji (olejków eterycznych), które łagodzą lub zapobiegają dolegliwościom, infekcjom i niedyspozycjom tylko w drodze inhalacji (BREMNEss 2004).

Terpeny z kwiatu lawendy mają własności tonujące, lagodzą stres i nerwobóle, działają aseptycznie i żółciopędne. Zapach kwiatów i liści lawendy uspokaja, roślina jest zatem stosowana w stanach lękowych i depresyjnych oraz w leczeniu bezsenności. Działa przeciwbólowo i antyseptycznie (BREMNESS 2004).

Ważnym sposobem eksponowania proponowanego pola lawendowego jest wyniesienie go $\mathrm{w}$ rabacie ponad poziom gruntu, dzięki czemu lawenda będzie również dostępna dla osób z problemami natury fizycznej i sensorycznej. Podwyższona rabata lawendowa umożliwi latwy kontakt $z$ rośliną i glebą bez konieczności schylania się i kucania. Podwyższone kwietniki i rabaty są stałymi strukturami ogrodowymi. $Z$ powodu swych rozmiarów nie są przenośne. Zasadniczo są to pozbawione dna konstrukcje wypełnione glebą. Biorąc pod uwagę ograniczenia związane z zasięgiem rąk osoby siedzącej czy używającej wózka inwalidzkiego, podwyższone rabaty i kwietniki powinny mieć ok. $60 \mathrm{~cm}$ wysokości (wysokość $46 \mathrm{~cm}$ jest najlepsza dla osoby siedzącej na krawędzi rabaty i dla dzieci, a $76 \mathrm{~cm}$ - dla osoby stojącej). Podwyższone grządki powinny być zbudowane tak, by użytkownik miał swobodny dostęp do całej płaszczyzny roślin. Podwyższone rabaty i kwietniki mogą być wykonane np.: $z$ drewna, kamienia, betonu czy innych trwałych materiałów. Ponadto otaczające strefę V wyższe krzewy zapewniają poczucie intymności.

\section{ROŚLINNOŚĆ}

Kompozycja układu roślinnego opiera się na pełnej adaptacji istniejącego drzewostanu, $\mathrm{z}$ uzupełnieniem układu o dodatkowe gatunki drzew i krzewów związane $z$ terapiami (ryc. 6). Schemat rozmieszczenia użytego materiału roślinnego dzieli ten materiał na: drzewa istniejące, drzewa adaptowane $\mathrm{w}$ drodze przesadzeń (według projektu gospodarki drzewostanem), drzewa dosadzane, krzewy oraz powierzchnie naturalnego runa, które występuje na opracowywanym terenie $\mathrm{w}$ związku $\mathrm{z}$ bogatym drzewostanem oraz sąsiedztwem pobliskich lasów.

Proponowany materiał roślinny zastosowany w koncepcji ogrodu terapeutycznego ma uzupełniać przewidziane $\mathrm{w}$ programie funkcje oraz umożliwiać kreatywne wykorzystanie roślin $\mathrm{w}$ wybranych zajęciach terapeutycznych. Zdecydowana przewaga drzewostanu to istniejące rośliny adaptowane do nowej koncepcji, jednak proponuje się przesadzenia i uzupełnianie niektórych gatunków. Drzewa dosadzane to przede wszystkim brzoza brodawkowata (Betula pendula Roth) tworząca terapeutyczny zagajnik $\mathrm{w}$ jednym $z$ wnętrz programowych $\mathrm{w}$ strefie II. Strukturę roślinną ogrodu uzupełniono o nieistniejącą wcześniej warstwę krzewinek i krzewów ozdobnych. Wśród nich zaproponowano między innymi: w grupie krzewów wyższych - pigwowiec pośredni 'Elly Mossel' (Chaenomeles superba 'Elly Mossel'), dereń świdwa 'Midwinter Fire' (Cornus sanguinea 'Midwinter Fire'), rokitnik wąskolistny (Hippophae rhamnoides), bez czarny 'Aurea' (Sambucus nigra 'Aurea'), $\mathrm{w}$ przystosowanych siedliskowo stanowiskach zaproponowano grupy z różaneczników, w tym: różanecznik 'America' (Rododendron 'America') i różanecznik 'Rasputin' (Rododendron 'Rasputin').

Pośród grup i kompozycji niższego piętra zaproponowano barwne krzewy, między innymi: berberys Thunberga 'Aurea' (Berberis thunbergii 'Aurea'), berberys Thunberga 'Kobold' (Berberis thunbergii 'Kobold') oraz śliwa karłowa odmiana karłowa (Prunus pumila var. depressa). Natomiast w strefie V dużą wyniesioną rabatę z lawendy wąskolistnej (Lavandula angustifolia).

Ponadto w przewidzianych na terenie ogrodu rabatach i kwietnikach proponuje się bogate kolorystycznie kompozycje $z$ bylin i sezonowych roślin kwietnikowych. Opcjonalnie układy te można uzupełniać o rośliny cebulowe, które pojawiają się i kwitną przez cały okres wiosenny, umożliwiając przebywanie na terenie ogrodu już w bardzo wczesnych okresach pozimowych.

\section{WYBRANE ELEMENTY WYPOSAŻENIA}

Poszczególne wnętrza o różnych funkcjach mają być w myśl koncepcji wyposażone w elementy uzupełniające i wspomagające terapię oraz codzienne funkcjonowanie obiektu. Dlatego w przestrzeni z polem do 
akupresury główną funkcję pełni ścieżka wysypana otoczakami (kamieniami o zaokrąglonym kształcie). Otoczaki nie są stabilizowane $\mathrm{w}$ gruncie, jedynie włożone wzdłuż wykonanego na kształt ścieżki koryta - wzmocnionego wąskimi obrzeżami po bokach. Ulokowano tam również ruchome kolorowe siedziska pozwalające na różnorodną aranżację przestrzeni (ryc. 7). Proponowane rozwiązanie siedzisk $z$ tworzyw sztucznych opiera się na konstrukcji stalowej, poruszającej się po stalowej szynie. Kolory siedzisk powinny być zgodne $z$ zaproponowaną kolorystyką i nawiązywać do barw elewacji budynku szpitalnego. Przewidywana maksymalna liczba siedzisk na tym terenie to 20 sztuk.

Podstawowe cechy proponowanych w koncepcji siedzisk:

- odporność na wysokie i niskie temperatury, siedziska nie powinny odkształcać się podczas upałów i nie mogą pękać w czasie najsilniejszych mrozów,

- odporność na warunki atmosferyczne oraz na promieniowanie UV,

- odporność mechaniczna, w tym na akty wandalizmu, dzięki specjalnie wzmocnionej konstrukcji ze stali nierdzewnej,

- trwałość barw,

- estetyczne kształty, brak ostrych krawędzi,

- mocowanie za pomocą drążka z kulką o średnicy większej niż rozstaw szyny, co uniemożliwi demontaż osobom niepowołanym,

- lekkość, co ułatwi użytkownikom przesuwanie siedzisk.

W zakątku kontemplacyjnym przewidziano umieszczenie podniesionej rabaty lawendowej. Ten dość duży element kompozycji stanowi zaokrąglony pojemnik wykonany $z$ betonowego obrzeża, które utrzyma kształt rabaty zgodny z koncepcją, bez odgraniczania roślinności od strony podłoża. Proponuje się, aby glebę, w której będą rosły rośliny, usypać 5-10 cm poniżej górnej krawędzi obrzeża.

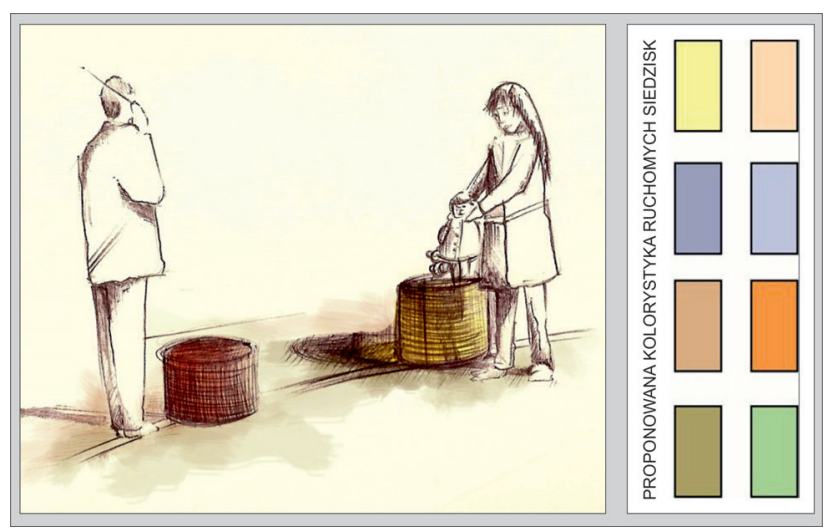

Ryc. 7. Koncepcja mobilnych siedzisk Źródło: opracowanie A. Walerzak.

Fig. 7. Concept of a mobile seats

Source: developer by A. Walerzak.
Aby ułatwić użytkownikom ogrodu korzystanie z kapieli słonecznych oraz wypoczynek na drewnianych podestach w strefie I i IV, zaleca się ustawienie na tym terenie drewnianych, przenośnych leżaków (do wyboru). W niesprzyjających warunkach pogodowych i zimą leżaki powinny być usuwane.

\section{PODSUMOWANIE}

Projektant, architekt krajobrazu tworzący koncepcję zagospodarowania ogrodu terapeutycznego powinien szczegółowo analizować czynniki, które tworzą uwarunkowania danego terenu, ponieważ mają one zasadniczy wpływ na proces projektowania.

Najważniejsze czynniki, które należy uwzględnić, aranżując przestrzeń dla przyszłych użytkowników, to między innymi:

- profil placówki, przy której powstanie ogród terapeutyczny. Staje się on wyznacznikiem konkretnych potrzeb poszczególnych użytkowników, często mocno skonkretyzowanych i zróżnicowanych, - lokalizacja obiektu,

- stan obecny zagospodarowania terenu, uwzględniający: szatę roślinną, układ komunikacji, elementy wyposażenia,

- mikroklimat na danym terenie,

- potrzeby użytkowników szpitala określone na podstawie przeprowadzonych badań sondażowych,

- rola roślinności w aspekcie: terapeutycznym, leczniczym, kompozycyjnym, plastyczno-estetycznym.

W zagadnieniach $z$ grupy psychologii społecznej $\mathrm{w}$ procesie projektowania ogrodów specjalnych należy zwrócić baczną uwagę na problemy dotyczące osób niepełnosprawnych. Ich integracja $z$ pełnosprawnymi powinna stać się podstawą $\mathrm{W}$ tworzeniu środowiska oraz zasad wspólistnienia społecznego. W tak projektowanych i realizowanych przestrzeniach publicznych człowiek niepełnosprawny nie odczuwałby swojej inności, z którą musi się codziennie mierzyć.

W przypadku wybranej grupy ogrodów specjalnych, jakimi są ogrody przyszpitalne, poprawa warunków przestrzenno-kompozycyjnych wydaje się nieodzownym elementem służącym uzyskaniu przez te obiekty podstawowych funkcji. Forma i jakość zagospodarowania tego typu obiektów oraz uwzględnienie $w$ ich programie elementów hortiterapii może być ważnym elementem leczenia.

\section{LITERATURA}

BREMNESS L. (2004): Wielka księga ziół. Wydawnictwo Wiedza i Życie, Warszawa.

CZARnecki W. (1968): Planowanie miast i osiedli. T. 2 i 3. Państwowe Wydawnictwo Naukowe, Warszawa: 547-553, 622-639. 
DĄBSki M., Dudkiewicz M. (2010): Przystosowanie ogrodu dla niewidomego użytkownika na przykładzie ogrodów sensorycznych w Bolestraszycach, Bucharzewie i Powsinie. Teka Komisji Architektury, Urbanistyki i Studiów Krajobrazaowych. OL PAN, Lublin: 7-17.

Palej A. (1991): Kształtowanie przestrzeni dla dzieci w miejskim środowisku mieszkaniowym. Monografie Politechniki Krakowskiej. Tom 109. Wydawnictwo Politechniki Krakowskiej, Kraków.

TACZANOWSKA E. (2005): Różne kształty wody - projektowanie ogrodów. Woda w ogrodzie. Działkowiec, numer specjalny 2: 20-25

WALERZAK A. (2007): Koncepcja zagospodarowania ogrodu przy Wojewódzkim Szpitalu Zespolonym im. Ludwika Rydygiera w Toruniu. Praca inżynier- ska pod kierunkiem dr inż. E. Sokołowskiej-Myjak, Wyższa Szkoła Ekologii i Zarządzania w Warszawie, Warszawa. Materiał niepublikowany.

ZalewsKa K., Walter E. (2011): Rośliny w zabawach dziecięcych czyli o „frytkowych drzewach”, „kwiatkowej zupie” i zbiorowiskach „militarnych". W: M. Drozdek (red.). Rośliny do zadań specjalnych. Oficyna Wydawnicza Państwowej Wyższej Szkoły Zawodowej w Sulechowie, Sulechów: 101-112.

For citation: WalerZak M., Walerzak A. (2019): Zieleń o specjalnym przeznaczeniu na przykładzie koncepcji zagospodarowania ogrodu przy Wojewódzkim Szpitalu Zespolonym w Toruniu. Steciana 23, 3: 31-40. doi: 10.12657/steciana.023.003 